\title{
Aircraft for Sea Service
}

\section{Lieut. F. L. M. Boothby R.N.}

To cite this article: Lieut. F. L. M. Boothby R.N. (1912) Aircraft for Sea Service, Royal United Services Institution. Journal, 56:412, 751-780, DOI: 10.1080/03071841209423748

To link to this article: http://dx.doi.org/10.1080/03071841209423748

曲 Published online: 11 Sep 2009.

Submit your article to this journal $\pi$

Џll Article views: 10

Q View related articles $\sqsubset$ 


\title{
THE JOURNAL \\ OF THE \\ ROYAL UNITED SERVICE INSTITUTION.
}

\begin{tabular}{lll}
\hline VOL. LVI. & JUNE, 1912, & No. 412. \\
\hline
\end{tabular}

[Authors alone are responsible for the contents of their respective Papers.]

\section{AIRCRAFT FOR SEA SERVICE.}

\author{
By Lieut. F. L. M. Boоthby, R.N. \\ On Wednesday, 17th April, igi2. \\ Rear-Admiral A. H.S. B.ICon, C.v.o., D.S.o., R.N., in the Chair.
}

\section{INTRODUCTION.}

UP to the present the science of aeronautics, as a whole, has suffered from the fact that the two main schools of thought-I mean the aeroplane and airship schools-have not worked together in a spirit of mutual co-operation, but have been at pains to decry the merits of the one type and to praise their own particular favourite, as might well be expected when vessels so different in design and functions have to be discussed. Experts are apt to take a one-sided view of the capabilities of their favourite, to the disadvantage of its rivals. The result is that both branches șuffer more from the criticism of their opponents than they gain from the advocacy of their friends. Looking at the matter.from the point of view of utility to the Navy, both types have advantages for service at sea-one for comparatively short flights and the other for more extended cruises, whilst there is a large region where their functions overlap. It is, therefore, as an advocate of both types that I venture to address you to-day. I have been so fortunate as to be able to watch the development of the aeroplane since the days when Mr. Roe designed the first British aeroplane, and since the first IVright machines appeared at Sheppey. I have also been in a position to watch the building of an airship. The fact that opportunities of being intimately acquainted with both types have not been given to many officers is my only excuse for delivering this lecture. There are a large number of officers more qualified to speak on acroplanes and airships than I am, and they will, I trust, deal gently with me when we come to the discussion if I do not 
credit their particular type of aircraft with its full capabilities. Before discussing the specific uses of aircraft, let us examine the performances we may reasonably expect from modern types. I am assuming throughout that all aircraft engines consume $.7 \mathrm{l}$ lbs. of petrol and oil per horse power hour.

\section{AEROPLANES.}

I think it will be generally agreed that a likely winner of the military competition will be a machine of about 70 h.p., and a speed of zo miles per hour. If this is so, it will be able to carry petrol and oil for $4 \frac{1}{2}$ hours, and $350 \mathrm{lbs}$. in addition, according to the conditions of the competition. Floats for Naval Aeroplanes need weigh no more than a landing châssis, so that this type of machine will be equally suitable for sea service. There is, therefore, the $350 \mathrm{lbs}$. weight to veer and haul on. If we put two men weighing $120 \mathrm{lbs}$. each into the machine, the remainder of the weight can be devoted to fuel and oil, and the machine can remain in the air for 6.7 hours. If, on the other hand, only one man is carried, he can remain up for nine hours. Personally, I do not believe that one man could control an aeroplane for so long a period, navigating and keeping a good look-out as well, certainly not if he were searching for submarines. It is in this direction that a good automatic stability device would prove of value, as, by reducing the work and fatigue of the pilot, one man would be able to scout efficiently for a long period, and so enable the maximum endurance of the machine to be attained. So far, a reliable automatic stability device has not been developed, but, is likely to be so in the near future. However, for the present we will assume that the two-man arrangement is a normal one. If, in addition, we fit the very necessary wireless apparatus, with a 30 mile range, we must reduce our possible time in the air, so that, if we say we may expect the constructors to provide us with a two-man twin-control aeroplane capable of a speed of 70 knots for six hours, we shall not be asking too much; but, at the same time, we are not likely to get more at present. The distance this type of aeroplane is capable of covering is 420 miles. Such a machine should be capable of starting from a ship or from the water, and of alighting on the water. It does not seem likely that the aeroplane will be able to alight on a ship except in the finest weather. If there is the slightest wind, eddies are formed around the ship which will make alighting on board dangerous. Any motion on the ship will make matters worse. When an aeroplane is alighting on the ground, it may be struck by a puff of wind which lifts it a few feet, but in this case the pilot alights a few yards further on than he originally intended. In a ship there is no "further on" except in the shape of bulkheads or barbettes. By and by, when we get a gas-engine ship, with a long flush deck, alighting may be possible, but in the meantime an aeroplane that wishes to return to a ship must 
alight on the water alongside her and be hoisted in like a picket boat.

The lantern slides show various types of aeroplane floats suitable for use in smooth water. The defect of all flat-bottom floats is that in any sea they hammer badly, and have to be built very strong and heavy to withstand this. An Italian named Forlanini has designed a motor-boat weighing two tons and driven by a 200 h.p. engine which attained a speed of 47 knots. The boat is fitted with hydroplanes, one above the other in the form of a ladder, fore and aft, the size of the hydroplanes decreasing as they get lower. The boat climbs out of the water on these hydroplanes until resting on the lower ones only, and it seems probable that in this direction we must look for the development of aeroplanes capable of starting from and alighting on the water.

\section{THE AIRSHIP.}

Engines giving an output of 400 h.p. will drive a welldesigned 2 I ton airship at the rate of about 47 miles per hour, requiring 3 tons of petrol and oil for the purpose in 24 hours. The equivalent distance through the air is I,200 miles. By using the formula

$$
\text { Speed at } x \text { power }=\frac{\text { Full Speed }}{\sqrt[3]{\frac{\text { Full Power. }}{x \text { Power. }}}}
$$

we find that at half power she will be able to proceed for $4^{8}$ hours at 37.3 linots, which is equivalent to a distance of 1,790 miles, or for four days at quarter power, which would give a speed of 29.6 knots, or a distance of $2,8+1$ miles. Three tons is a small amount of fuel for $a 21$ ton airship to carry. If she were starting on a really long cruise, she could take two tons more than she is able to lift statically, the extra lift being given by the horizontal rudders and engines, assuming that the ship could get up speed by running along the surface of the water; but, of course, full speed could not be attained under these circumstances. Large radius of action in a dirigible, apart from its value in scouting, is highly desirable for the following reasons: In the first place the lift of a dirigible falls off as hydrogen gradually absorbs the air and diffuses-a process known as osmosis, so that a good reserve of buoyancy is desirable. With the materials in voguc a year ago the falling off in lifting power and consequent radius of action was fairly rapid, the gas-bags requiring refilling about once in three wecks. Happily, it seems that in the near future refilling once in three months will be sufficient, improvement in the gas-holding qualities of fabrics recently tested being so great, whilst at the same time their weights have been considerably reduced. Referring to the Report of the Advisory 
Committee for 1911 , we find on page 71 that fabrics have been tested having as low a permeability as .I litre per square metre per 24 hours, and three samples with less than 6 litre per square metre, compared with a permeability of ten litres per square metre which was considered good'a short time ago, whilst the new fabrics do not deteriorate with exposure to any extent, a great contrast to the older types of gas-bag material.

Some figures for the "Adjutant Reau" are interesting. She was filled for over two months before making her wellknown cruise of more than 500 miles. During this period she lost only 2 per cent. of lift due to osmosis, whilst the daily leakage was never greater than I.7 per cent. After being filled for six weeks she was actually able to lift 3,400 kilos of ballast, or Ioo kilos more than when she was first filled (this, of course, being due to the action of the barometer), and during the whole period of two months the ballast lifted did not fall below 3,000 kilos. It should be noted that she is not constructed of the very latest type of fabric.

Again, it may be desirable to arm airships with guns to drive off the enemy's aircraft, in case we should wish to look into his ports or approach his fleet, or to prevent his aircraft from obtaining information we wish to conceal. Unless there is a large margin of flotation to draw. on, mounting guns or carrying explosives must dangerously reduce the radius of action, especially in bad weather. Considerable radius of action and complete equipment therefore necessitate large airships, and for this reason the non-rigid and semi-rigid are not likely to be of so much use as the rigid for ocean work in the future, their size being limited with the materials at present at our disposal. To realize this, let us, talie any type of airship and double its length and diameter. IVe will call the length $L$ and diameter $d$. The lift increases as $L d^{2}$, and will, therefore, be eight times as great. The resistance, and therefore the engine power, increases as $L d$, and is therefore four times as great. If, now, we consider the airship as a beam when we double its length, the load remaining the same, and in its same relative position, we double its bending moment. As, however, we have shown that the weight has increased eight times, the bending moment is increased 16 times, or as $L^{4}$. It is therefore obvious that it is useless to contemplate increasing the size of airships and leaving the increased weights lifted in their same relative positions. They must be distributed along the hull, so that the bending moment is not increased. In the ideal airship there would be no bending moment whatever; each section of the ship would take a due proportion of the lift. There is little practical difficulty, especially in the rigid type, in getting this distribution of load, so that the hull weights would increase in proportion to $L d$, or nearly so; that is, would be multiplied by four in this particular instance, whilst gas-bags and outer cover would be increased in the same proportion, so we see that in a rigid airship, all 
weights, hull, gas-bags, outer cover, engines for the same speed, all increase in a less proportion than the volume and lift, the exception being the stresses on the transverse frames, due to lift on the top and the load underneath. This might increase as $L d^{2}$; but by tying down the gas-bags, or, as I consider preferable, by running wires through them, this ratio of increases can be reduced, and certainly need never be exceeded; whilst it should be noted that it is perfectly feasible to carry part of the load, such as petrol tanks, on the top of the airship.

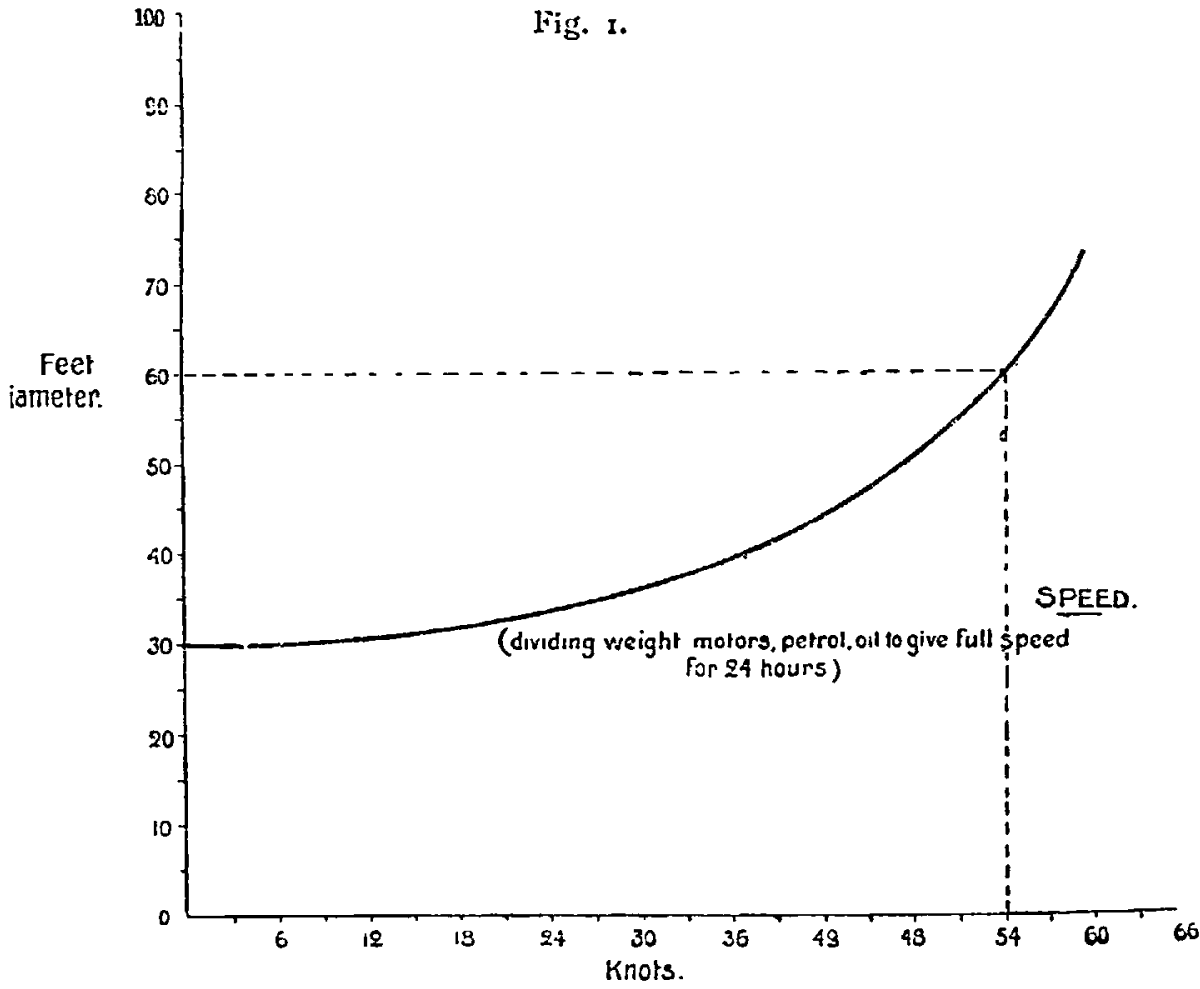

The stresses and strains in the non-rigid are the same; but, as we increase the size, we find that the weight of the gas-bag increases at a greater rate than the volume and lift. -Doubling the length and diameter as before, the surface, and therefore the weight, of the fabric would increase as $L d$; but, having doubled the diameter (the internal pressure being lept constant), we must also double the thicliness of our fabric. This weight will increase as $L d^{2}$, or at the same rate as volume and lift, but, owing to the increased speeds obtainable from our larger ships (and neglecting any increase necessary for increased bending moment, should there be any), we must increase our internal pressure, which will again require increased thickness and weight of material, so that our gas-bag weight is increasing 
at a greater rate than our lift, and a time will come when no increase in size will be of advantage, the actual limit depending upon the material used.

In looking ahead it seems probable that airships will increase in size as other ships have done, and therefore it is advantageous to work on a type which seems capable of great expansion. I have drawn some curves based on the "Schwaben," showing what we might expect from her as we increase her size. I cannot state that they are absolutely accurate, but I think they will be found to be approximately so, assuming that we are able to distribute the load so

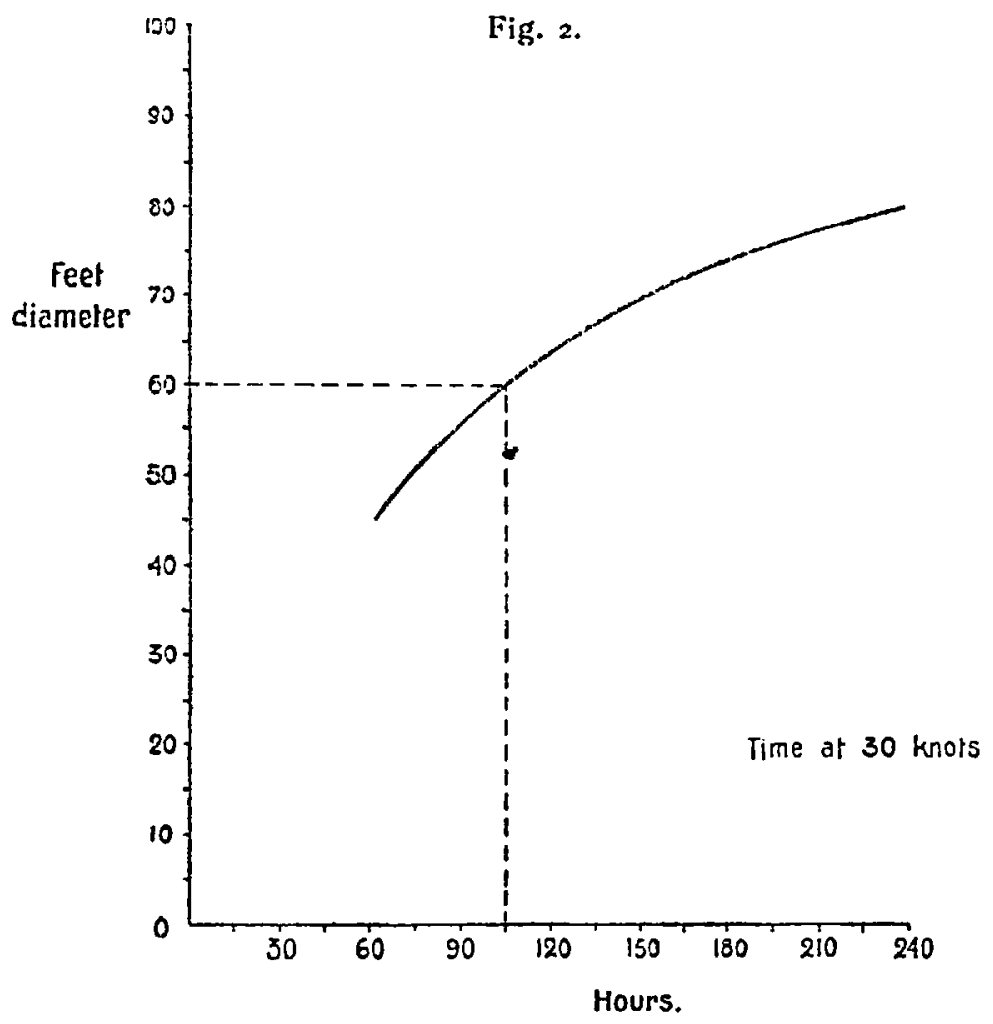

as not to increase the bending moment at any point. Count Zeppelin is a patriotic nobleman, who, having designed a magnificent weapon for his country, does not intend to assist any possible enemy by giving away information, so that details about his ships are scarce and difficult to obtain. Taking the details we do know, and the facts obtainable about other ships, we are enabled to draw the rough curves shown, and they are probably accurate within to per cent. either way. It is, of course, understood that the length is increased proportionately to the diameter. It will be noted that the figures I suggested, 
namely, 400 h.p., giving 47 knots speed for 24 hours, are not borne out by this diagram. This, $I$ am of opinion, is due to the "Scliwaben" not being of the most desirable form, either for constructional reasons or because it was found desirable to increase her lift at the expense of speed. Professor Zahm found that least resistance is obtained when the head resistance is equalled by that due to skin friction; this occurs when the bow of the airship is struck at two diameters and the stern at nine, the part in between being parallel. Judging by the photographs, these conditions are not fully satisfied in the "Schwaben," which may account for her requiring greater

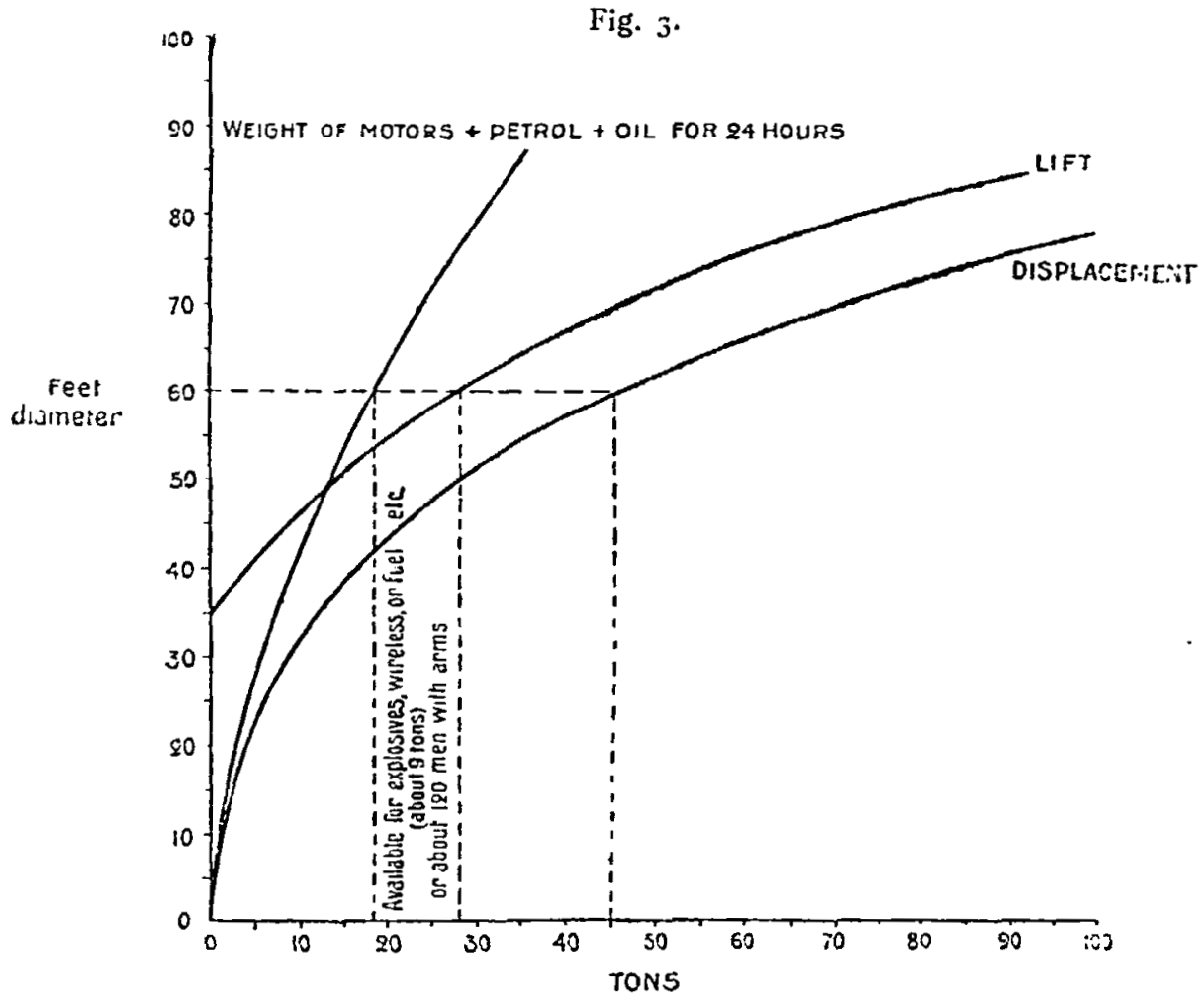

horse-power for a given speed than anticipated. The necessity for not increasing the bending stresses as we enlarge the ship emphasizes the need of an efficient water recovery plant, so that as the petrol is used it can be replaced by an equivalent weight of water. As theoretically 148 per cent. is recoverable from the exhaust gases, it is probable that there will be little diffculty in recovering 100 per cent. But an even greater proportion than this is desirable to allow of compensating during the day time for ballast lost at night due to the cooling of the gas. It will be seen from the curves that an airship some 60 feet in 
diameter will have a speed of 50 miles per hour for 24 hours with a good margin of lift (nine tons), available for extra petrol and oil, guns, explosives, wireless, or whatever may be desired.

It is rather interesting to see what happens when the weight is put into fuel. We find that the ship is now capable of 50 knots for 44 hours, equivalent to 2,200 miles, or 192 hours at 30 knots, equivalent to 5,760 miles, which, I think, you will agree are rather startling figures.

Further points in favour of the rigid as compared with the non-rigid and semi-rigid are that in the first place the gas-bags are subject to no stresses except to those due to the head of gas, whilst in the second case it is necessary to exert additional pressure by pumping air into the ballonets to maintain the shape. The pressure on the envelope may be greatly increased by her progress through the air, not at the bow, where the internal pressure should about equal the external, but at the stern, where, if the airship is not of stream line form, or if any deformation takes place, a partial vacuum may be formed, and the stresses on the envelope will then be the algebraic sum of the internal and external pressures. Again, in the rigid type, should she be seriously wounded, say by a splinter of a shellbullets do not matter particularly to either type-only one gasbag would be damaged, and it is probable that the ship would still be able to remain in the air by using the lift obtainable from her aeroplanes; at any rate, her speed of descent would be slow. IVith a non-rigid, a serious wound means instant collapse. The Italians, I believe, have fitted some diaphragms inside their ships, with small holes in them, with a view to preventing the airship being completely deflated immediately she receives a large wound, but it is of doubtful value. These diaphragms also have the effect of checking the surge of the hydrogen towards the bow should it be tilted upwards, and the drop of air into the after part of the ballonets, another defect of the non-rigids.

The advantages of the non-rigid over the rigid type appear to be that the deterioration of the hydrogen due to osmosis may be somewhat reduced by keeping it under pressure and so increasing its density in proportion to air, whilst, for army work it may be deflated in emergency, and the gas-bag packed up. This quality is not likely to be of great use at sea, as anyone who has had to handle a deflated gas-bag on the water will affirm. If, in addition, we take into consideration the ease of mooring a rigid ship by the bow, although the possible claims of the Astra-Torres type, with its internal roping, must not be forgotten, I think it will be granted that the rigid is the most promising type for us to develop for sea service, though the non-rigid may be of great use for harbour defence and training purposes. The main characteristics of a rigid or modern type are a number of longitudinal girders, generally built up in triangular form, running from bow to stern, and joined together in some cases by spirally winding round them a 
system of similarly constructed girders, or else by connecting the longitudinals by transverse frames and staying them to each other by wires for mutual support. Inside the frames go the gas-bags, 16 or so in number, and on the outside the outer cover, leaving a foot or so air space between the two. The engines are suspended below.

In our further remarks we will consider a ship of this type capable of 50 knots for nearly two days, such as we have seen by the curve could be built, and such as Count Zeppelin could probably turn out next year if he so desired, and such as I trust British firms are also capable of constructing.

\section{EFFECT OF WEATHER ON AIRSHIPS.}

Weather has such an important bearing upon the subject of airships that it is necessary to consider the question briefly.

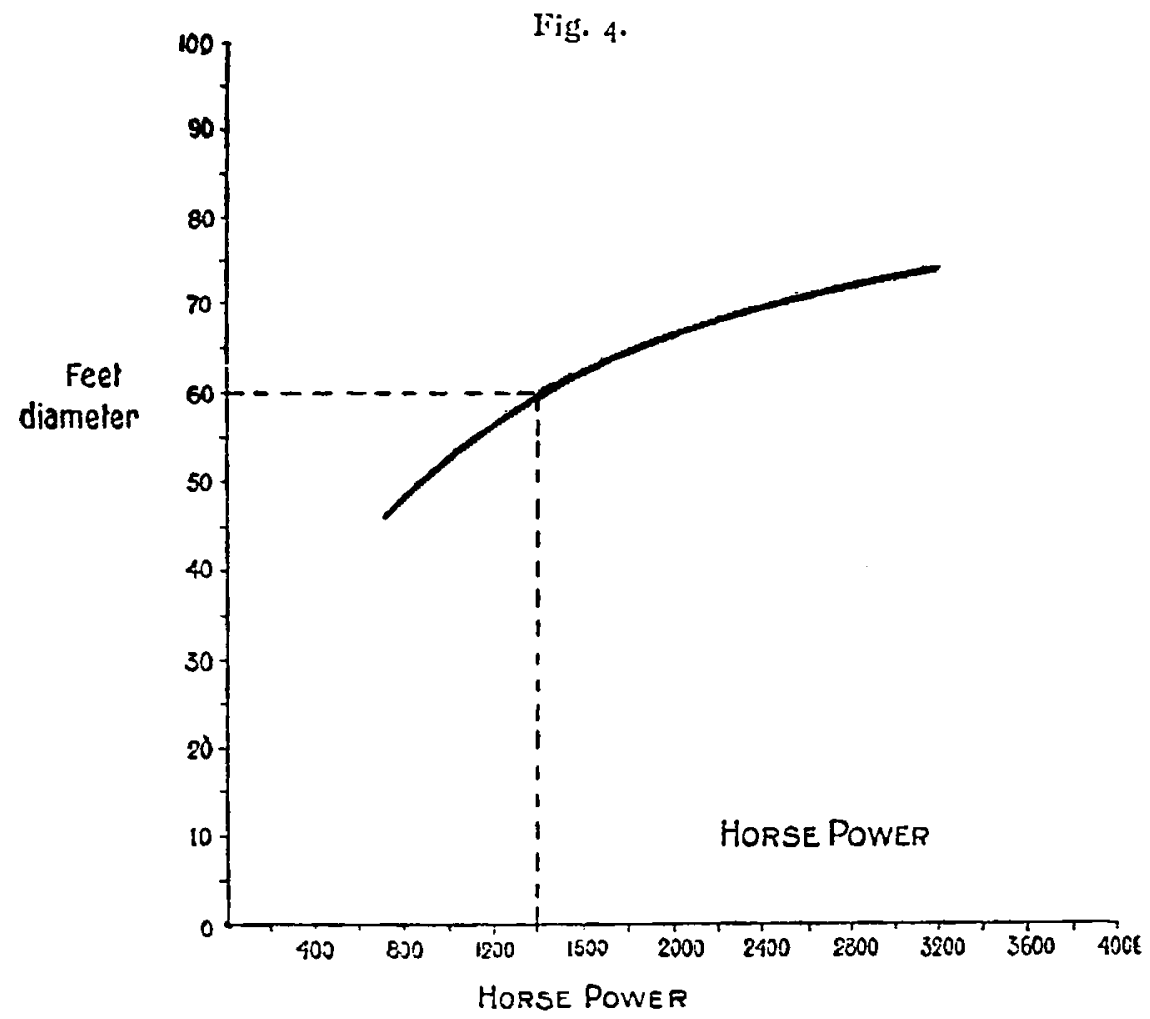

Unlike the aeroplane, which need not be sent up unless the weather conditions are considered suitable, an airship for sea service must be prepared to meet all weathers. An airship that has to live in a shed is of little use, as, when she is urgently required, the wind may blow across the mouth of the shed for days and make it impossible for her to come 
out. Revolving sheds are a possible solution for small craft, but for large ones they are out of the question if only on the score of expense. There are two methods by which an airship not in use may live through a gale. The first method, and the best, of doing this is to have a fixed post in the centre of a lake, the top being the same height as the bow of the airship when the gondolas are just touching the water, the bow cap being secured as close to the post as possible. Lying in this way, should the ship be struck by a side wind, she heels over slightly, due to the drag of the gondolas through the water. The act of her heeling orer, and her sideways motion, compresses the air under her, and, the gondolas being shaped to assist this, the airship rises until the gondolas slither over the surface of the water or rise just clear of it. The ship may swing through very considerable angles in this way, the only difficulty being to get boats alongside, but then, it is difficult to get boats alongside any ship in rough weather. By this method, provided the post is strong enough, there is little likelihood of her breaking adrift. The pressure on the bow of a "Schwaben "when the wind is blowing at the rate of 100 miles an hour is about 13 tons, and the strength of the bow should be well over $7^{0}$ tons. One objection to this method is that it increases the wear and tear of the outer cover, as the ship is always in the position of being under way. This is a very small objection, as the outer cover is comparatively cheap and is easily replaced. This system, first introduced for naval airship No. I, has since been adopted by the Army, "Astra-Torres," and Siemens-Schuckert firms, I believe, with complete success, but, of course, when moored over land the airship is kept clear of it, buoyancy being given for the purpose. In heavy weather it may be desirable to keep ships moored over water in the air, but for winds up to $45 \mathrm{~m}$.p.h., they ride perfectly comfortably on the surface, which is a great convenience, as men can be moved about without troubling about ballast.

The other possible method is to build large airship harbours, consisting of a considerable area surrounded by a high wall or bank, into which airships can be drawn from overhead. We are all aware how the air is deflected upwards by any obstruction, and it seems quite possible to construct a harbour on these lines which will deflect the wind over the ships inside. There are several natural harbours I know of, such as a valley between Barrow-in-Furness and Dalton, where it is practically always calm, and there must be very many such places in hilly countries. Old quarries may be useful in this direction, or even large dry docks. On the whole, however, the post in the centre of a large sheet of water seems to hold the balance of advantages, and will probably be the method adopted where local circumstances permit of it.

When we come to consider the behaviour of airships at sea in relation to the weather we shall find that wireless telegraphy 
is of the greatest assistance. A point in favour of the airship is that, unlike the aeroplane, it can receive as well as send a wireless message. Such importance is wireless likely to assume, that $I$ imagine in the near future the Meteorological Office will have to be fitted with its own wireless station and work on its own special tune to transmit warnings and advice to aircraft. Dr. Shaw, of the Meteorological Office, assisted by Mr. Dines, has been working out what would happen to an airship starting at noon daily from Plymouth, and trying to

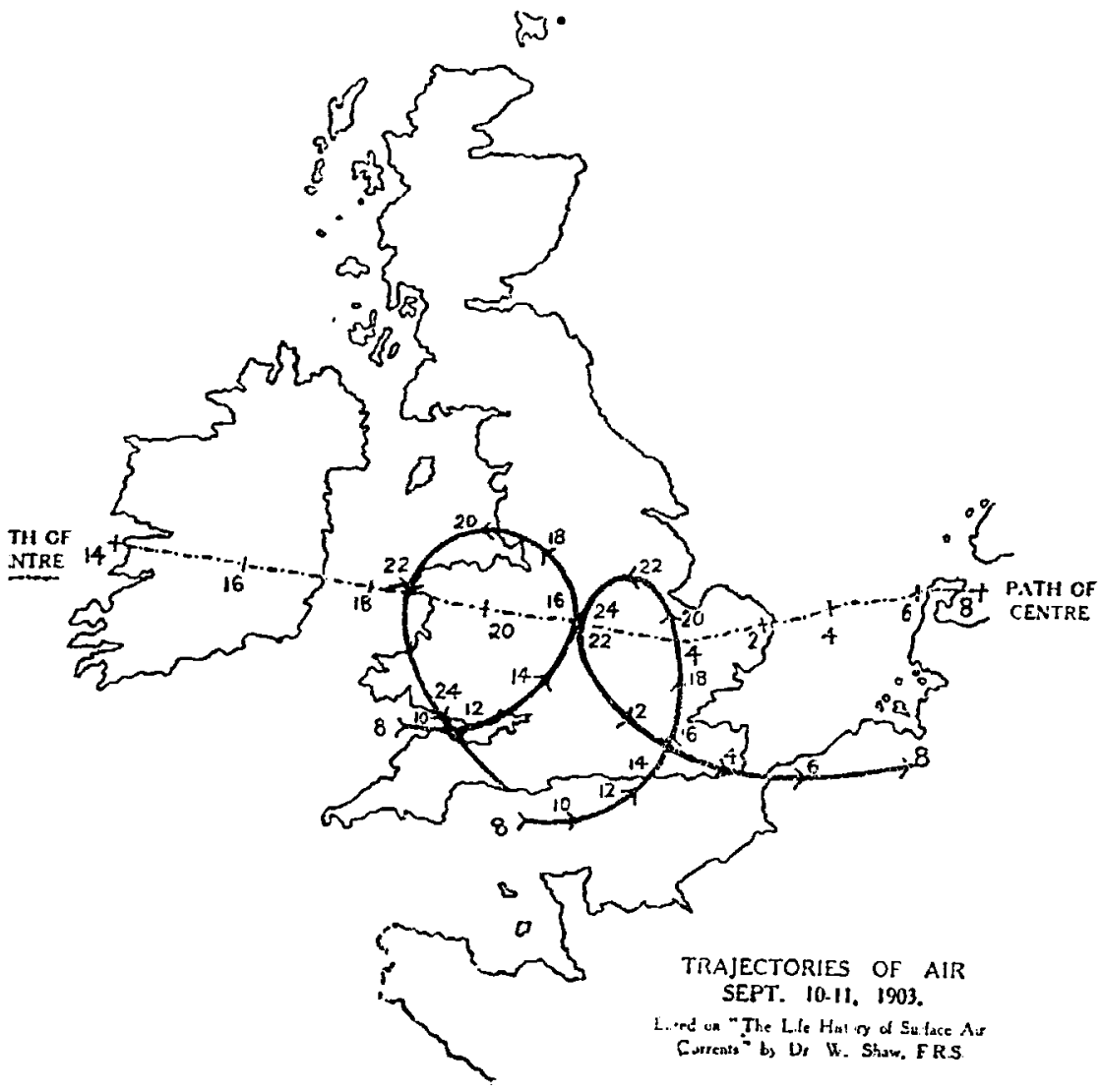

look into Yarmouth, returning at once when she has done so. The distance in a direct line is 250 miles, and on every occasion from February 2Ist to March 8th, the airship got to Yarmouth, except on March and and 8th, when she did not start, the weather making it obviously impossible to return within a reasonable time. The longest time taken to get there was eight hours, and the shortest four-and-a-quarter, though she was only steaming at 30 knots in this last instance, and getting back was very slow work as it was assumed she 
was only a 40 knot ship, so she only made five knots over the earth. In this connection the importance of good control in the vertical plane is manifest, as had this theoretical airship been able to keep very close to the surface she would have only found about half the gradient wind, whereas it was assumed that she would have to keep at such a height that she would be subject to a wind equal to two-thirds of it. The following example will show how useful wireless telegraphy would prove on occasion. Often it is a perfectly feasible plan to proceed around the centre of a storm, returning with the assistance of the N.IV. to S.IV. winds found on the other side. This fact is shown by the accompanying chart, copied from the Life History of Surface Air Currents, by Dr. Shaw, showing two cases in which a free balloon would have been carried around the centre and back again. It is not absolutely certain in those cases in which the particle of air approaches the centre very closely that it is the actual one to come away from it again; but in any case the one originates so close to where the other vanishes that they may be considered as the same, and, given engine power, there should be no difficulty in getting around the centre at all, although the distance traversed in doing so may be very great indeed at times. In this particular instance an attempt was made to get round the centres, and had the storm been moving on its normal easterly course, all would have been well. As it was the storm centre altered its course north, and the attempt to cross its path failed. Had the airship received information to this effect she would have flogged away against the wind, supposing she had no post harbour or parent ship to make fast to, or else run south into calmer weather, coming back when the weather was quieter.

An interesting point to notice is that any wind whatever, from any direction, reduces the radius of action of aircraft, which is a maximum in a calm. Let $x$ be the time flying with the wind and $y$ the endurance. Then the sum of the speed and wind multiplied by $x$ equals the difference of the speed and wind multiplied by $(y-x)$. $y$, is known, so $x$ and consequently the radius of action can be found. For winds not from ahead or astern it is necessary to resolve the speed and wind along the proposed course and then work out the formula in the same way.

In dealing with aircraft which have large radius of action we must enlarge our ideas of distance. I should not be surprised if in the near future it was considered quite an ordinary event for an airship to run 600 miles north or south to avoid the central regions of a storm. Dr. Shaw points out that it is highly desirable for aircraft to avoid the S.IV. to N.M' quadrant of a circular storm on account of the prevalence of "line squalls," such as destroyed H.MI.S. "Eurydice" off the Isle of IVight. There has been one case of a free balloon being caught in a squall of this description and being brought to earth. Whether a dirigible could weather one we have yet 
to learn, but probably so, as, if well handled, her horizontal rudders will assist her in addition to her being able to discharge ballast. A phenomenon of these line squalls is that they have a downward trend accompanied frequently by hail or snow, the weight of which tends to bring the airship down. Summing up, we see that from aeroplanes we may expect to be able to scout over comparatively short distances as compared with the longer ones a dirigible is capable of, and that an aeroplane is capable of taking shelter in bad weather while a dirigible is not; and, having regard to their respective limitations, we will now see how these types of aircraft may be used in connection with the Navy.

\section{AEROPLANES FOR SCOUTING PURPOSES.}

Taking the case of aeroplanes first, it is obvious that they cannot keep station on fleet for long, and, as their speed is not variable, they will be forced to fly in circles-a somewhat wasteful procedure. Aeroplanes, therefore, must be carried in ships and sent up when needed. In calm weather, such as is found in the Mediterranean, it is conceivable that they may be of the greatest use. Using the formula

$$
\mathrm{d} \text { (miles) }=\sqrt{\frac{3}{2} \mathrm{~h} \text { (feet) }}
$$

we find that an aeroplane at a height of 5,000 feet could see large objects such as a fleet up to 80 miles, and objects could frequently be seen at this distance in clear weather. It - would, therefore, pay a cruiser searching for the enemy to keep an aeroplane constantly aloft. The sea there in summer is generally smooth, and an aeroplane alighting on the water close to a ship would probably be hoisted on board in about five minutes. The cruiser, steaming 20 knots, and with an aeroplane constantly in sight, could search a very large area in the course of twelve hours. A point worth noticing is that if an aeroplane had a wireless apparatus with a range of 80 miles, she could in the day time proceed 80 miles ahead of her parent ship, still keeping her within sight, and informing her at once if anything was in view at the time. With the wireless apparatus of limited range that aeroplanes are likely to carry, they will have to close their parent ship to a distance of about 30 miles before they can get their news through-an unfortunate but necessary waste of time, which after all only amounts to about three-quarters of an hour. It will be seen that on a fine weather station aeroplanes facilitate the search for the enemy to a very great extent. It is a rather different matter when we consider their use in the North Sea. There, the average range of visibility is something in the neighbourhood of six miles. The weather is frequently bad. It may be easy enough to start an aeroplane from a ship even if it is blowing quite hard, but picking it up again will not be so easy. In this respect aeroplanes are similar to torpedoes. One can start them from a ship all right, but everyone is devoutly 
thankful to see them on board again. One can better imagine than describe the feclings of a captain of a ship searching for an enemy with the aid of an aeroplane when the aeroplane's engines fail and cause it to alight on the water some 30 or 40 miles away from him. He must either sacrifice it, if time will not permit of his picking it up again, or two or three hours of valuable time must be wasted in looking for it, picking it up and getting under way again. It must also be remembered that

\section{Example: To search from Cape Clear to the Blaskets.}

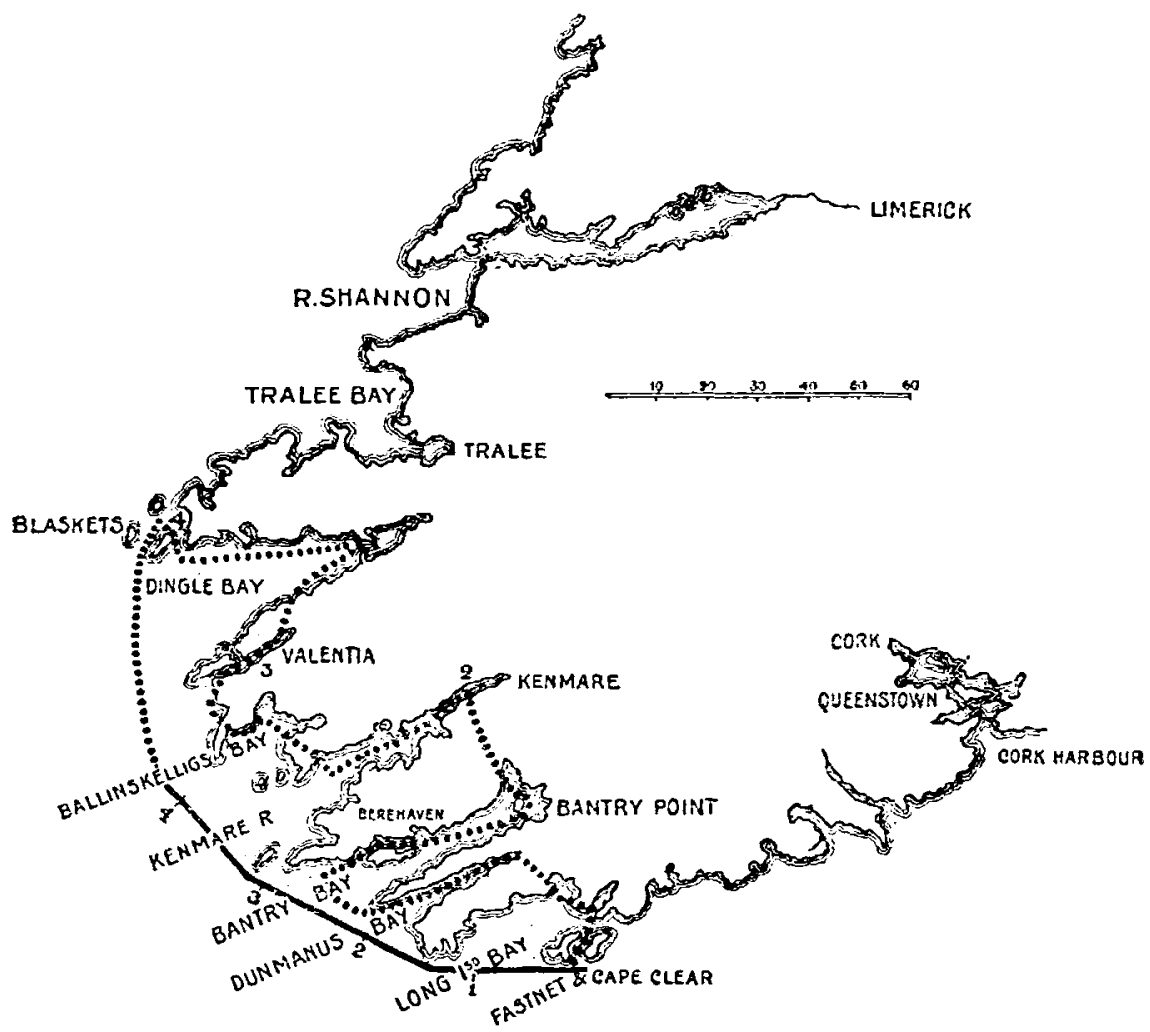

With Aeroplane : Ships speed, 2I. Aeroplane speed, zo knots.

Time required, $4 \frac{1}{2}$ hrs.

Without Aeroplane: Ships speed, 20 knots (allowing I knot less for turns.) Time required, 15 hours.

once the aeroplane loses sight of a ship, it is doubtful if it will ever find her again. We have only to take the unfortunate case of the late Mr. Cecil Grace, who, starting from Calais in a slight haze, missed Great Britain only 21 miles away. It is true that naval officers should be more practised in the use 
of the compass than he was, but, even allowing for that, it will require a very skiful, and, I might add, lucky navigator of an aeroplane to find his parent ship if he loses sight of her. for half an hour, more especially if his parent ship was also under way. In this connection it might be considered whether, if kites were sent up to a height of about 1,500 feet, they might not often be of use for scouting purposes, their advantages being that they cannot be lost, and the observer is in direct telephonic communication with the ship. A situation where aeroplanes will, however, be of the very greatest use is in searching a deeply indented coast for the enemy's ships and torpedo craft. A chart of the S.W. coast of Ireland shows the course to be pursued by a 2 I knot scout searching for hostile torpedo craft and by the same scout when assisted by an aeroplane. It will be seen that the aero. plane could search the whole coast in lour-and-a-half hours, and regain her ship. The scout, if searching all the bays and harbours herself, supposing we reduced her speed on an average to 20 knots to allow of her frequent turns, would take 15 hours to do this work, and, if the days were short, two days would be required. Of course, an aeroplane, scouting at this rate, could not be certain of locating torpedo craft or submarines deliberately attempting to hide themselves. That work would be better done by an airship; but it should have no difficulty in locating anything in the shape of a commerce destroyer or some similar craft. A point against the aeroplane in this connection is that its parent ship must approach fairly close to the coast, even if the visibility is as great as 20 miles, in order to keep the aeroplane in sight, thus exposing herself to attacks from submarines and mines. Probably the procedure that would best be followed would be for the parent ship to send up her aeroplanes and retire to sea again, rendezvousing off some prominent point some four or five hours later. Should the parent ship be lost or sunk, any information the aeroplane may have obtained becomes useless, and the aeroplane becomes a gift to the enemy.

A service in which the aeroplane will probably prove of great value is that of locating mines and submarines in narrow waters. In the estuaries of rivers and other muddy places mines will, of course, be invisible, and the periscope of a submarine submerged in a tideway will probably not be observed by the fast moving aeroplane. In clear, smooth water everything should be visible, especially with a bright sun. All seamen know how a ship may pick her way through a coral reef when conned from aloft, and all fishermen know how the movements of fish in a stream may be watched from a bridge. Any ships approaching waters where mines or submarines may be expected will have a good chance of getting through unscathed if they choose a nice bright day and have aeroplanes searching the sea in front of them. Another use for them will be to watch narrow channels, so as to give warning of the approach of the enemy to our own submarines and mine layers. 
We are particularly fortunate in that we have bases on narrow channels in many parts of the world. It seems probable that aeroplanes will attack submarines with success provided the submarine is submerged. A good pilot, passing close above the submarine, should be able to drop a charge of guncotton, arranged to explode well under water, within a few feet of the submarine. This would destroy the submarine or bring her to the surface; but not the aeroplane, as she would have passed some distance from the scene of the explosion when it took place, further than in the case of steamboats firing spar torpedoes.

\section{AIRSHIPS FOR SCOUTING PURPOSES.}

Turning to airships, we see that a 50 knot ship can keep station on a fleet steaming 15 knots, provided the wind is not blowing more than 35 miles per hour from ahead or more than 47 on either beam. As the wind draws abaft the beam so she is able to keep station in a stronger breeze, and if the wind is right aft and blowing 65 miles an hour, she can still keep station on her fleet by steaming against it. That is to say that on most days an Admiral could use her just as he would a cruiser, making use of her increased range of vision on a clear day, with the additional advantage that he could send her to look into an enemy's port, knowing that she is immune from damage by submarines and mines, and far less liable to damage from gunfire than any ordinary ship, while her wireless range is just as great. The question of losing her in thick weather does not apply, as the airship is self-contained and can find her own way about. A sextant is now made which allows of a sight being taken even when no horizon is visible, and, from experiments made with this, there should be little difficulty in fixing the position to within five miles. Certainly the conditions for taking sights are far more favourable than in a destroyer. The vibration on the top of the airship, with the engines running full power, is practically nil. Fogs are often low lying, and it is conceivable that in the future, an airship may be prepared to rise above the fog and report the position of the fleet below. If it is found impossible to rise high enough to see the sun, the airship can be navigated very well by dead reckoning, her leeway being judged by dropping some article or smokeproducing chemical on the sea and taking bearings on it; or else it is possible to stop engines and drift with the wind a few minutes, when the strength and direction of the wind can be found in a similar manner.

A tremendous advantage that the airship has over the aeroplane is that it can work at night, as well as by day. It seems probable that from a height of 1,000 feet the glare of the funnel of a warship would be visible at night, and, should this prove to be correct, an airship should have no difficulty in hanging on to the enemy's fleet by night as well as by day, 
and keeping the Admiral informed of their movements. For blockade work, too, they can be in a given position for long periods. For instance, taking the mean of 35 years' observations from the Sailing Directions, an airship could have watched Pembroke every day, except for 23 in the year. Again, the table below shows the strength of the wind at Oban, at 7 a.m. and 6 p.m. on every day of IgII. The wind here shown is the gradient wind usually found at a height of 1,500 feet, and this is

TABLE SHOWING GRADIENT WINDS AT OBAN, 191x.

\begin{tabular}{|c|c|c|c|c|c|c|c|c|c|c|c|c|c|c|}
\hline $\begin{array}{c}\text { Wind } \\
\text { Velocity } \\
\text { M. P. H. }\end{array}$ & & Jan. & Feb. & Mar. & Apr. & May & June & July & Aug. & Sept. & Oct. & Nov. & Dec. & Total \\
\hline \multirow{2}{*}{$\begin{array}{l}100 \text { or } \\
\text { over }\end{array}$} & $7 \mathrm{a} . \mathrm{m}$. & - & - & - & - & - & - & - & - & - & - & 1 & 1 & $2^{*}$ \\
\hline & 6 p.m. & - & - & - & - & - & - & - & - & - & - & 1 & $=$ & $t^{*}$ \\
\hline \multirow{2}{*}{90} & $7 \mathrm{am}$ & - & - & - & - & - & - & - & - & - & - & 1 & 1 & $2 *$ \\
\hline & 6 p.m. & - & - & - & - & - & - & - & - & $=$ & - & $=$ & - & $0^{*}$ \\
\hline \multirow{2}{*}{$80-89$} & 7 a.m. & - & $=$ & - & - & - & - & - & - & - & - & - & - & $0^{*}$ \\
\hline & 6 p.m. & - & - & - & - & - & 二 & - & - & - & - & - & - & $0^{*}$ \\
\hline \multirow{2}{*}{$70-79$} & 7 a.m. & - & 1 & - & - & 1 & - & - & - & - & - & 3 & - & $5^{\circ}$ \\
\hline & $6 \mathrm{p.m}$. & - & $=$ & 1 & - & - & - & - & $=$ & $=$ & 1 & - & 3 & $5^{*}$ \\
\hline \multirow{2}{*}{60.69} & 7 a.m. & - & 2 & - & 1 & - & - & - & - & - & 1 & - & - & $f^{*}$ \\
\hline & $6 \mathrm{p.m}$. & - & - & - & - & - & 1 & - & - & - & - & - & - & 10 \\
\hline \multirow[b]{2}{*}{50.59} & $7 \mathrm{a} . \mathrm{m}$ & 1 & 5 & - & - & 2 & 3 & $I$ & - & - & 3 & 1 & $i$ & $20^{*}$ \\
\hline & 6 p.m. & 1 & 2 & $t$ & 1 & - & - & - & - & 1 & 2 & 4 & + & $16^{*}$ \\
\hline \multirow{2}{*}{$40-49$} & 7 a.m. & 2 & 2 & 5 & 4 & 1 & 1 & $\mathbf{I}$ & 3 & I & 1 & 4 & 2 & $27^{4}$ \\
\hline & $6 \mathrm{p} \mathrm{m}$. & 7 & 6 & 3 & 3 & 3 & 4 & - & 3 & 1 & 2 & 6 & 6 & $44^{t}$ \\
\hline \multirow[b]{2}{*}{$30-39$} & 7 a.m. & 12. & 5 & 7 & 6 & $I$ & 4 & 6 & 4 & 7 & 3 & 9 & 11 & $75^{t}$ \\
\hline & 6 p.m. & 14 & 3 & 10 & 4 & $I$ & 2 & 6 & 4 & 2 & 2 & 9 & 6 & $61 t$ \\
\hline \multirow{2}{*}{$20-29$} & $7 \mathrm{a} . \mathrm{m}$ & 11 & 4 & 12 & 6 & 10 & 5 & 10 & 10 & 8 & 9 & 8 & 10 & $103^{t}$ \\
\hline & 6 p.m. & 6 & 8 & 8 & Io & 9 & 7 & 11 & 13 & Io & 7 & 5 & 8 & 1024 \\
\hline \multirow{2}{*}{$\begin{array}{c}\text { Below } \\
20\end{array}$} & 7 a.m. & 6 & 9 & 6 & 14 & 16 & 17 & 13 & 14 & 11 & 14 & 3 & 2 & 1281 \\
\hline & 6 p.m. & 3 & 8 & 8 & 12 & 18 & 16 & If & II & 11 & 17 & 5 & 4 & $127^{\frac{1}{4}}$ \\
\hline
\end{tabular}

- On $5^{6}$ occasions wind velocity greater than speed of dirship (50 m.p.h.)

f On 337 occasions wind velocity less than speed of Airship (jo m.p.h )

generally double the wind found on the surface. But, taking the maximum gradient wind, it will be seen that there were only 56 occasions on which the wind recorded exceeded 50 miles per hour, so that we may take it that on 28 days of the year on an average a blockading airship would have been blown away. If we accept the principle that a gradient wind is double that near the surface of the earth, could the airship have kept 
low, there were only three occasions on which she would have been blown away.

The question of replenishing, with fuel and oil from a ship at sea will probably not be found difficult, even in bad weather, as it can be blown into her very rapidly with compressed air through torpedo charging pipes. Once an airship is in tow of her parent ship-and there should be no difficulty in getting in tow, as the airship would drag her bow hawser over the ship-it should be possible to send a charging pipe out along the towing hawser, to connections on the bow cap, communicating with the petrol, oil, and gas-bags.

A man on the bow cap, hauling his charging pipe out, would connect it as requisite. $\Lambda$ device brought out by EngineerCommander Metcalfe some time ago for the purpose of permitting a collier to be towed by a battleship in heavy weather, which I believe is now either supplanted by a better device or not found necessary, would, I think, be very useful for towing airships. 'This consisted of an ordinary recoil ram from a gun-mounting, working in the recoil cylinder, with the keyway removed and the piston made solid. The cylinder was then filled with water and connected to the air reservoir of a torpedo, which was loalf filled with water and then charged with air to a considerable pressure. This absorbed very heavy shocks and jerks with the greatest ease, and something of this sort will probably be of assistance when it is desired to tow large airships. There is, of course, a certain danger to an airship approaching a ship, or being towed by her, from the sparks from the funnel; and it is desirable to fit baffle plates in the funnels and tow with a long scope. A gas-engined ship, of course, overcomes this difficulty. It may be that a large submarine will make a very suitable vessel to tow an airship at first, there being no danger of sparks in her case. Should an airship be caught at sea in heavy weather, with no ship available to make fast to and she does not wish to run far, it would be possible for her to lie at a drogue. Experiments in this direction have given very promising results, and it seems quite probable that with a good large drogue down and as near neutral buoyancy as possible, an airship will be able to reduce her speed of drifting to about a quarter that of the wind and maintain herself just on, or clear of, the tops of the waves by means of her aeroplanes.

In searching for hostile submarines the airship has an advantage over the aeroplane in that she can hunt slowly and carefully with four times the number of lookouts. She can also attack them, as an aeroplane might, by dropping guncotton, but she could not come so close to her target, so she would have less chance of dropping the charge sufficiently close to do any damage, though this might be more than compensated for by the superior instruments and greater charge she could carry. To keep aircraft off, submarines would have to remain on the surface, where they are liable to be attacked by ordinary ships, so, when once they are located, their position 
will not be rery enviable. Once the battle fleet know the whereabouts of the submarines they can easily avoid them, and the long-range wireless telegraphy of the airship is a very great advantage here, as she can pass information without losing sight of the enemy; in fact, wireless is at present the most important part of the equipment of aircraft, practically doubling their range and utility, and once they have got important information through, it does not so very much matter what ultimately becomes of them. Another possible use of airships is that of repeating ship in a fleet action. Being clear of smoke and out of range of hostile fire, signals could be easily made and read; in fact, the general view of a fleet açtion will be much better obtained from aloft, so much so that it is conceivable in future that a commander-in-chief may find it advantageous to direct his fleet from an airship at a good height, notwithstanding his natural desire to lead his fleet into action personally.

If we come to consider what damage could be done by aircraft dropping large quantities of explosives, say in the neighbourhood of a ton weight, it opens up great possibilities for attacking dockyards and such like places. It seems improbable that aircraft will ever be able to do much damage to battle fleets at sea, but should it be possible to explode large quantities of guncotton in a basin, or in the neighbourhood of lockgates, the effect would probably be disastrous to all ships lying, inside. Whien we come to consider the large number of torpedo craft a commander-in-chief would be prepared to sacrifice to destroy an enemy's repairing resources, and to. damage his ships lying in basin, I think it will be agreed when the question is studied that if we put the equivalent cost in money into airships, we should have a far greater chance of success, and probably do infinitely more damage.

\section{THE ARMING OF AIRSHIPS.}

IVe have not so far taken into consideration that the enemy would have aircraft as well as ourselves, but, naturally, this would be the case. It follows, then, that we should have fighting in the air, either in an endeavour to force our way through the screen of hostile aircraft to obtain the information we required or to prevent him from doing the same. Therefore airships will have to be armed, and I believe it is true that the French and German airships are being so armed; in fact, I have here a specification for an airship for one of these Powers, givingthe weight of gun and the number of rounds to be carried, but whether the ship has actually been ordered or not I do not know.

$$
\begin{array}{llrr}
\text { Volume, not to exceed } \ldots & \ldots & 35.3,000 & \mathrm{c.f} . \\
\text { Length not to exceed } \ldots & \ldots & 262 \mathrm{ft} . \\
\text { Total height of ship not to exceed } & 82 \mathrm{ft} .
\end{array}
$$

(N.B.-The car is a long way below the envelope). 
The ship would have sufficient lift to carry the following weights :-

14 persons at $165 \mathrm{lbs}$. each $\ldots 2,3$ Io lbs.

Fuel, oil, and water for 20 hours'

$$
\text { flight } \quad \ldots \quad \ldots \quad \ldots \quad 4,180 \text { lbs. }
$$

Machine or automatic guns $\ldots . .220$ lbs.

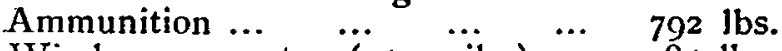

Wireless apparatus (250 miles) ... $385 \mathrm{lbs}$.

Searchlight (to light up landing place from a height of $600 \mathrm{ft}$.) I 10 lbs.

Ballast necessary for attaining altitude of 5,500 feet above sea level, besides fuel, \&c. 4,840 lbs.

$$
\text { Total ... ... ... 12,837 lbs. }
$$

\section{Or about $5^{\frac{3}{4}}$ tons.}

On the last occasion I spoke here, during the discussion on Capt. Burke's lecture, 1 I mentioned that rigid airships could mount guns on the top, and I am afraid some of the audience imagined that I was drawing the long bow. In partial proof that it is possible, however, I have here a slide of photograph of Naval Airship No. I with five men on the top. If you take the weight of a man at 120 lbs., we have more than double the weight of a Maxim gun, and I can assure you that five is not by any means the maximum number who have been working on the top at the same time. Mounting them in the gondolas is, of course, easy, as everyone will agree. Aeroplanes will doubtless be armed too, probably with some sort of shot gun rifle or repeating pistol. It matters not for our argument how aircraft are armed so long as we agree that they will carry weapons. Once fighting starts we logically come to fleet actions in the air, each side endeavouring to concentrate the greatest number at the decisive point. This at once points to the necessity for one Aerial Service, and I am very glad to see that it is proposed to train Naval and Military aeroplane officers at one school. It is a commonplace that if two squadrons of different nationalities are combined against a single fleet the single fleet has the advantage. Similarly, if at any time we had to concentrate Naval and Military aircraft against an enemy who has but a single air service, we should be at a disadvantage, because we should not have been. able to practise and work together properly.

\section{FUTURE DEVELOPMENT OF AIRCRAFT.}

As regards the future development of aircraft, there is, as I have endeavoured to show, no visible limit to the growth of the rigid airship. They are on the same footing in this respect as water ships. As regards aeroplanes, the case is rather different, and unless some more economical motor is found, it

1 See December, I9II, Journat, page 1635 . 
does not look as if they would be able greatly to exceed twelve hours in the air, carrying only one man. If we take the aeroplane that we have been discussing to-day and put the whole weight she can carry into petrol and oil, allowing nothing for the pilot, she could fly for I I $\frac{1}{2}$ hours. If, now, we double the size, we double the weight of fuel carried, but we double the resistance, so that we double the horse power required to move her at the same speed, and nothing is gained. For practical sea work the grave doubts of finding their parent ship again in foggy regions like the British Isles will probably limit their use for long distance scouting. Possibly four hours endurance will be found sufficient, and the weight so saved will be utilized to provide more powerful wireless or carry a larger supply of guncotton for use against submarines, or, again, it may be devoted to carrying an extra man for fighting in the air.

The chief objection to airships is their expense, though four can be built for the price of one destroyer. Unfortunately, in addition, they require sheds for occasional docking, posts to lie at when not in use, or else special harbours, and all this means more money. Aeroplanes, on the other hand, are cheap -about the price of a torpedo. The sheds for docking them are cheap, and they can be easily carried on ships with but little alteration. For harbour defence, for work with our submarine flotillas and increasing the range of vision of ships by scouting around them and attacking submarines they are excellent; but for long distance work, blockade work or forcing a way through a screen of hostile aircraft you must have the airship. The airship bears to the aeroplane the same relation as a battle cruiser does to the torpedo boat. Building battleships whilst not neglecting torpedo craft has always been Great Britain's policy on the sea, and appears to be Germany's policy in the air, whilst the French still continue their policy of depending largely upon torpedo craft on both sea and air. I trust that in the future our policy in the air will be the same as it has been at sea; and I have little doubt that as the science of aeronautics develops the command of the air will prove to be necessary for us if we wish to keep the command of the sea. The fleet without aircraft to assist it will be at a tremendous disadvantage as compared to one with them.

In conclusion, I must heartily thank all those who have assisted me in the preparation of this paper.. I have written to various airship officers of the Navy and Army, to the Aeteorological Office and the Advisory Committee Laboratory, and, not only has every question been kindly and promptly answered, but they have all gone out of their way to assist with information. When busy men such as these will give so much time and trouble in the preparation of tables, etc., in order to assist a stranger, it points to their intense interest in aeronautics, and augurs well for the future of the science in this country. 


\section{DISCUSSION.}

Baron Roenne said that his opinion was that many people overvalued the importance of aeroplanes and undervalued the services of airships. The larger they built a ship the more economical she was in the ratio of efficiency to the cost of running. The same geometrical and mechanical principle applied to the airship. If they doubled its linear dimensions -even if they made its walls three times as thick-they would get eight times the cubical space and eight times the buoyancy. But they would require only four times the propelling power to drive it at a given speed. The principle of the cube and the square would always be on the side of the large ship.

Tlie result was just the opposite when they doubled the size of an aeroplane: the ratio diminished. It would, therefore, be impracticable to build very large aeroplanes. A well-known aviator had recently written as follows:-

"What is not a commonplace yet, but may soon become one, is that the next great war will be fought in the air, and that roo superDreadnoughts will then be as useless as a fleet of cockleshelis. Go to Hendon or Brooklands and learn how near is that possibility."

Could anyone believe that an aeroplane would ever discharge such deadly projectiles as a super-Dreadnought, or would ever sink a battleship? No doubt they would be of great value for scouting and despatch work in war time, and also to attack the enemies' aircraft with rifles, not with machine guns as had been suggested; machine guns were good on land, but it was impracticable to carry them on aeroplanes. An airship, on the contrary-say of 44,000 cubic metres capacity, 200 metres long and 18 metres diameter, with rigid bow, and engines of $1,200 \mathrm{H} . \mathrm{P}$., producing a speed of 55 miles per hour, capable of moving easily vertically and horizontally, and of standing still in its element, and floating for some days-would be of great value both for naval and military purposes, especially for destroying forts and towns at night.

No doubt he would be asked, "Are we able to build such a vessel to-day." He replied, "Yes "; the industry of to-day could furnish everything desirable for aerial navigation, and that even to a remarkable degree of perfection. It was only a question of correctly appraising and utilizing the means at their disposal.

Mr. Grahame White said that he had been extremely interested in Lieutenant Boothby's valuable lecture, but unfortunately it had been devoted very much more to airships, about which he understood very little, than it had been to the heavier than air machines. His experience in lighter than air machines started in Paris somewhere about 1902-3, when he had the pleasure of visiting M. Henri Deutche le Meurte at St. Cloud, for the purpose of seeing the first trials of his dirigible.

\section{A Trip in the "Ville de Pau."}

Later he was down at Pau in the south of France, where he was learning to fly aeroplanes. He was on one occasion a passenger in a flight made by the "Ville de Pau." It was only about once a month that this dirigible would venture out of its hangar, though the heavier than air machines were flying every day. It took about three or four hours to get this dirigible out with the aid of two or three regiments or battalions of French soldiers. There could not have been more than about a ten miles an hour wind blowing, but they experienced the very greatest difficulty in getting the balloon clear. There was a large space 
in front of the shed, but in getting up they fouled the shed and carried away a lot of guide ropes. When they had made a flight in a straight line, the captain tried to turn round and come home. He first put his helm hard over to port, 'but the vessel took not the slightest notice of the rudder. He then put the helm hard over to starboard, and after seven minutes she seemed to go to port and they eventually got round. They made about 20 various attempts to get back to the dirigible's shed, ten miles away. When they eventually reached the shed their trail ropes were all let down, and they fouled everything. They carried away all the telegraph wires and nearly pulled the shed down. Eventually some of the soldiers got hold of the guide ropes, and in about another hour they were all safely landed. He had never yet ventured up in another dirigible, and he was not very likely to. The Lecturer had in the course of his paper put forward the advantages of the dirigible. He (the speaker) frankly stated that he did not think the dirigible had any future before it whatsoever. Its great cost, for a start, was very much against it. A large fleet of aeroplanes could be purchased and equipped for the cost of one dirigible. And he did not think there had been one single dirigible that had lasted more than three months from the date of its birth, while very few of them had come through their trials at all satisfactorily. A great deai had been said about the marvellous way in which the naval dirigible rode at her anchorage at Barrow; but within a month of her birth that dirigible was a complete wreck. If the Admiralty rebuilt that dirigible they would be throwing their money down the sink. The Lecturer had said something about these dirigibles cruising in 50 miles an hour winds; or even, in one instance, in 65 miles an hour winds. He did not think the Lecturer or any of this audience would like to be a passenger in a balloon under such conditions. He candidly did not think that any dirigible could live in such a wind. First of all there was the huge bulk of the envelope; then it could not be held to the ground, and if it was once liberated he doubted if it would ever be got down again. It required a tremendous staff to look after such a vessel.

Then the Lecturer had referred to the question of the speed of these dirigibles. Some very big speeds were mentioned-speeds which he had never heard of being attained by dirigibles except under the most ideal weather conditions-in a perfect calm.

Then, again, the Lecturer had remarked that aeroplanes were more or less fair weather machines, and he had put it as an advantage held by the dirigible over the aeroplane, that it could go out under weather conditions which the aeroplane could not go out in. He was diametrically opposed to that statement. He affirmed most emphatically that aeroplanes -heavier than air machines-would fly, and fly satisfactorily, in winds in which dirigibles had never been known to be outside their hangars, and that this had been proved within the last few weeks. That was a very great point in favour of the aeroplane-that it could take the air under conditions where the dirigible would not venture up. Again as regards the destruction of the dirigible, he would rather be in an aeroplane than in a dirigible under war conditions. He thought he would have a very much greater chance of getting off scot free in an aeroplane than in a dirigible. He did not think the dirigible would have much chance of getting to land safely again against a fleet of aeroplanes. First of all they must remember the superior manner in which the heavier than air machine could rise; its greater control, and its speed. It would simply waltz round the dirigible. It would get right above it and drop bombs on to it and probably 
annihilate it, before the dirigible would wake up and know that there was any aeroplane in the neighbourhood.

Another question referred to by the Lecturer had been the time that a pilot could control an aeroplane; he said he did not think it possible for one man to control an aeroplane for a period of longer than six-seven hours.

The Lecturer : Nine hours, I said.

Mr. Grahame White said it was an accomplished fact. It had already been done, and therefore there was no doubt about it. scout."

The Lecturer: I added as well "And to keep an efficient lookout, to

Mr. Grahame White said his experience of flying in an up-to-date aeroplane was that he was as happy there as in an arm-chair, and-that being the case-he did not see why he should not keep an efficient loolsout, just as much as one did when driving a motor. Of course, it was tiring; even driving a notor car for six or nine hours was tiring; but no more so than flying an aeroplane except under very adverse conditions.

Then he thought the Lecturer had stated that it was impossible-or that it would be impracticable-for aeroplanes to land on ships. He did not think that was so. A very strong wind would be of great assistance when landing on a ship for the reason that it would be quite possible for the ship to so manouvre that the aeroplane could alight on it practically at a standstill; so that if the wind was a very strong one the aeroplane would be practically stationary in the air. It would run into ropes to which sand bags could be fitted. He had seen aeroplanes alight on ships in that way before, and make most perfect landings without the slightest danger to the pilot or to the machines; and those were demonstrations which he himself would only be too pleased to carry out. It would be just as easy to land on a ship in calm weather for the reason that you got'the speed taken off your aeroplane by running into ropes stretched across the platform, so that if you ran into one rope it would take off the speed of the machine.

\section{Wireless Telegraphy on Aircraft.}

With reference to wireless telegraphy on dirigibles, at the present time, it was possible that the dirigible had the advantage of the aeroplane in that respect, merely for the reason that the dirigible was somewhat of older standing than the aeroplane, and that few of them had experimented at all with wireless on aeroplanes. That was simply due to the fact that the wireless engineers had not produced any instruments very suitable for the purpose. As soon as they did so he did not think they would be able to claim any very great advantage for the dirigible for wireless purposes. He was present in the United States when several very interesting experiments were made on aeroplanes with wireless. They were highly satisfactory, but as the Lecturer had quite rightly said, they were at short ranges, merely for the reason that the apparatus supplied by the wireless engineers was only made for short ranges, and that was the commencement of the experiments. The Lecturer stated in his paper that the apparatus only weighed 250 lbs., and if that would give a long range they could carry it on the aeroplane just as well as on the dirigible. As regards storms, was it not the fact that these storms raged at various altitudes? Was it not quite possible for a storm to take place anywhere between the earth and 6,000 and 7,000 feet altitude? IVould it not, therefore, be possible to rise above the storm? 
The Lecturer: I think not.

Mr. Grahame White said that was a question upon which he should very much like to be enlightened. At any rate, it was a fact that, at various altitudes, more or less constant winds were blowing. He had been up in balloons where he had crossed the same point seven times at various altitudes; which proved, for the sake of argument, that at 1,000 feet level there might be a due east wind blowing, and at the 3,000 feet level a due west wind blowing, and so on.

Those elements would be very much in favour of the aeroplane, which could mount so much quicker and come down so much quicker than the dirigible, so that an aeroplane could make use of those conditions in a very much more rapid manner. Even if the dropping of gun cotton in the neighbourhood of submarines did not put the submarines out of action, would not the explosion of the gun cotton in their neighbourhood cause such a concussion that it would probably kill everybody in the submarines? The Lecturer had also made the remark that he did not think the aeroplane would be of any use at night. It had already been demonstrated that it could be, and he thought there would be absolutely no difficulty in proving it. He himself had been flying in the air for two and a half hours in the dark, on his way towards Manchester, without any moon, stars or anything else, so there was no reason why it should not be done again. He thought the aeroplane would be just as satisfactory under night conditions as the dirigible.

\section{Aeroplane Destroyers.}

A great deal of attention was being given to scouting machinesmachines for reconnaissance and machines for despatch carrying. He was, of course, referring to heavier than air machines. But it appeared to him that little attention had been given to aeroplane destroyers, and he thought that was a point to which very great attention should now be given. He thought in the near future it would be necessary for those machines that were doing reconnaissance work, the scouting, to be accompanied by destroyers. In order to prevent the enemy's scouting machines coming over our line it would be necessary for aeroplane destroyers to be hovering over halfway between ourselves and our enemy in order to prevent the enemy's scouting machines from crossing the dividing lines. Those machines would have to be equipped with quick-firing armament to ward off the attacks of the enemy's aerial fleet, and to keep their scouting machines from crossing the dividing line.

With reference to bombs, he thought it was a pretty well-recognized fact that bombs did very little damage. On impact they sent up a discharge in the shape of an inverted cone, which did very little damage at the base. He believed that time bombs which would explode at a certain height above the ground, dropped on camps, fortifications, and so forth would do far more damage than the bomb they knew at the present time. Sir Hiram Maxim was, he believed, at present hard at work designing time bombs of that description.

Captain P. H. Wright said that there was one remark which Mr. Grahame White had just made as to rising above the storm on which it might be advantageous to seek more information. Was it possible to ascertain the vertical height of these barometric depressions such as the Lecturer had shown them in the course of a storm centre passing over England? Perhaps Dr. Shaw might be able to inform them if there was any limit vertically to these depressions. 
Baron Roenne said he would like to answer one or two of the points raised by Mr. Grahame White. The latter had mentioned that the pressure against the envelope of the dirigible at 50 knots would be very excessive. It was really only 75 kilograms per square metre at a speed of 56 miles an hour. Further, he thought one could rise in an airship over the storms fairly easily. It was quite possible, however, to construct a revolving dock or a turntable with a movable platform so that the airship could be anchored in its whole length and brought to the shed by means of motors and not by means of soldiers. As long as the ship was suspended in the air it was out of danger, and when landing was effected in the manner prescribed, the risk of impact was quite insignificant. They could also provide the vessel with a lift. The vessel, while suspended in the air, could be anchored to a battleship, or any kind of ship or intermediate station. The lift could be lowered to take on board petrol or explosives, and compressed gas in cylinders, or a gas tube to refill the vessel. Thus it would be seen that the airship could be supplied with its necessaries while up in the air. That would cause, not only safety, but also a great reduction in the cost of manipulating the airship.

Mr. Howard T. Wright said that the Lecturer had made out a very good case for the airship, but it seemed to him he had left out one consideration that Mr. Grahame White had referred to, namely, that an airship did not remain an airship for a sufficient length of time to get any real results from it. It seemed to have a great desire to return to its original elements. There seemed to be no doubt that an aeroplane had advantages over the airship in almost every particular, perhaps chiefly in speed. The aeroplane could, at the present day, do 80 miles an hour without any very great difficulty, and probably before very long it would be able to do very much more than that. As far as they knew at present the chief use of the aeroplane in war would be to get information. A battleship would probably carry is or 20 small aeroplanes, which could do about 80 miles an hour, so that in one and a half hours they could go out 50 or 60 miles, and come back and give information even without any wireless attachment. Twenty aeroplanes could probably be stored in a place something like 15 or 25 feet square; they could land on the water, be picked up and taken to pieces in a very few minutes, so that it was very difficult to see what the advantages of an airship would be over those of an aeroplane.

Mr. Charles Grey said he would like to endorse what Mr. Grahame IIhite and Mr. Howard IVright had aid in favour of the aeroplane, especially for naval work. It seemed obvious, speaking purely as a layman, that quite a number of aeroplanes could be stored on board even the smallest type of warship used to-day. An aeroplane could travel at approximately 80 miles an hour; it could go 20 or 30 miles from its ship at a height of 3,000 feet, so that the pilot could sweep the sea for a matter of at any rate 40 or 50 miles ahead of his ship. That must be an immense advantage over any form of airship. Possibly for coast work the dirigible might be useful, but he would like to know how the large rigid balloon could be of any use for real sea work.

The Lecturer, in reply, said : Mr. Grahame White's experience in an early dirigible was very interesting, but it must be remembered that that was at an early stage in the history of the dirigible. I imagine that $M$. Bleriot and the Wrights in their early aeroplanes had equally upsetting and disturbing trips. 

ago.

Mr. Grahame White said that those experiences were only two years

The Lecturer: Aeroplanes are cheap things. It is fortunate that is so, because private individuals can experiment with them, develop them, and get ahead. But rigids are expensive things, and it is necessary for the Government to experiment with that class of aircraft. That has not been done at present to any great extent. When, however, the same number of rigids or other types of airships have been built as aeroplanes have been up to date, I think you will find the position rather different: It is quite true, as Mr. Grahame White very rightly pointed out, that for the cost of one airship you can build a large number of aeroplanes. I am not saying that a large number of aeroplanes are not highly desirable; but it is no good having 2 ,ooo aeroplanes on Portsmouth beach if you want to get to Gibraltar. They could not get there, and an airship could. Similarly, it is no use having a number of motor boats round England if you want to get to New Yorl; ; you must have a liner. Then, again, with regard to the question of the length of time that dirigibles last; Mr. Grahame White has said that they have not lasted very long. But the "Schwaben" is going very strong now. I see in to-day's paper that she has already carried 2,000 passengers, charging them fro a head for the trip, so that she is doing very nicely, commercially. The behaviour of the naval airship at her mooring at Barrow was looked on as the most important trial with that airship. Everybody knows that these airships fly perfectly. The "Zeppelin" type has never had any accident whatever in the air, except due to the motor breaking down. We know when we get them in the air they will fly. All the accidents have occurred when at their mooring, and I think this method of mooring by the nose will marle an epoch in acronautics, and will solve the problem of airships for sea service. With regard to the question of the speed of airships, the "Schwaben" does 43 knots per hour, with 465 h.p. engines, and the "Victoria Louise" does 47.1 I look at the airship and the aeroplane as being in exactly the same relation as the battle-cruiser and the torpedoboat. We have enthusiastic torpedo-craft officers, just as we have enthusiastic aeroplanists, who say that the day of the battleships is done. We know perfectly well that if a torpedo-boat does get into such a position that she can get enough torpedoes into the big ship-say two-the latter is finished. But there are other officers who maintain that they will knock a dozen torpedo-boats out before they can come within torpedo range of their ship, and the question is not decided yet. We still have big ships, and we still have torpedo-craft, and the same discussion will go on with regard to air craft. Some people will say that aeroplanes can get above the airship and drop a bomb on to her and finish her. On the other hand, some people will say that the airship can have Maxims on top and below, and the crew armed with shot guns, and destroy any aeroplane that comes near her. Probably in another twenty years' time we shall find that problem is not yet settled.

\section{Vireless Telegrapiy.}

With regard to the question of wireless, the wireless installation for a 250 mile range adopted on the foreign airship mentioned weighs 385 lbs. An aeroplane can carry that weight, I suppose, but she would not get the

1 Since this paper was read it is reported that on May 3 Ist " $\mathrm{Z}_{3}$ " covered 438 miles at an average speed of 41 linots, commencing the flight at II P.M. -F.L.M.B. 
same range because she would not have the same sized aerial. There are a great many things that come into play in regard to wireless besides actual power and weight. There is the size of the aerial, suitably disposed instruments, and so on; and I do not think anybody has ever yet suggested that aeroplanes will be able to receive wireless messages in the air. One knows that at sea an immense amount of trouble is taken to exclude all noises from the wireless office in order that messages can be received, so that it is not at all likely that an aeroplane will be able to receive wireless messages.

\section{Alighting on a Ship.}

With regard to the question of alighting on a ship; I know that has been done in America in calm weather. Mr. Grahame White says that it can be done when it is blowing hard. I should not like to try it, and I should not like to see him try it, knowing the sort of eddy currents and draughts that you get round a ship. I think that an intermediate wind, between a calm and a wind of 60 miles an hour would be more troublesome than any of them. That question will, I suppose, be solved in the near future, but personally I should be very sorry to try, or to see anybody else try, to land on the quarter deck of any ship, except under the most favourable conditions, and then we know it can be done.

The Chairman: Gentlemen, we have had a very interesting paper and a very valuable discussion. It is always interesting to hear people spealk who hold totally divergent views. We have had the advantage of hearing Baron Roenne's views upon the use of the airship, and we have also had the advantage of hearing the views of Mr. Grahame White, who is, I suppose, the most expert aeroplanist in the world, and who has expressed a totally different opinion to that held by Baron Roenne. I must say as regards Mr. Grahame IVhite's remarks that his experience of an airship two years ago sounded very much like what the experience of an amateur, such as myself, might have been if I had been on an acroplane ten years ago. IVe must remember, I think, that when we talk of aeroplanes we are talking of the present, but when we talk of airships, we are talking of the possibilities of the future. Those who have to deal with questions of that sort, such as the authorities of the Navy, must not preclude the future, because the present does not give absolute success.

\section{Practical Difficulties.}

A fascinating view was put forward as regards the number of aeroplanes that could be carried on board a ship. It was said that the aeroplanes could be sent out in numbers and then brought back again, on board the war vessel. I have no reason to say that that is not possible; but I would remind you of the analogy of the second-class torpedo-boat. One of the most fascinating theories in my younger days in the Navy was that of the second-class torpedo-boat, which was to be carried on board ship-one ship had eight of them. The idea was that when the ship got near the enemy, who might be in harbour, the torpedo-boats were hoisted out; away they went after the enemy's fleet, sank them, and then they came back again. The thing was apparently the simplest thing in the world. As a matter of fact, battleships were fitted to carry these boats, but within three years of the time when they were put on board battleships every single one of them was removed. The theory was perfect, but the practice was impossible. The delays caused by getting the boats in, the small breakdowns on the boats when they were away 
made the whole scheme useless. In dealing with any of these questions we must be extremely careful not to express too definite opinions upon what may or may not be possible in the future. $\Lambda$ thing may be possible or not possible; when it comes to be tried practically, the thing that appears to be very simple often becomes very difficult, and equally often that which appears most difficult turns out to be really a simple matter.

Although in no way wishing to detract from the value of aeroplanes to the Navy, under certain conditions, anyone who seriously studies the strategical requirements of the British Isles, due to their peculiar geographical situation in Europe, must inevitably arrive at the same conclusion as the Lecturer: that if the airship can be properly: developed it is of considerably more use than the aeroplane as we know it now. I am quite certain that anybody who really studies the subject must come to that conclusion for very good reasons. It takes a good deal of looking into, but I think we may accept it as a fact. Prolonged endurance is necessary for prolonged reconnaissance; the air craft must possess the power of navigating accurately. The scout may be away for a considerable time at a considerable distance, in varying weathers, such as fogs, and he must keep his reckoning practically as accurately as is done on a ship, and that is one reason why there must be one, two, three, or four people in the same air vessel. If you want to get endurance of the craft you must have endurance of the crew, and to have endurance of the crew you must give them comfort. Mr. Grahame White has pointed out that he can fly himself quite comfortably for nine hours in an aeroplane, but if he has to do work and do it under bad conditions of weather, such as cold and exposure, he will not be in his normal state. If the men are to do their work thoroughly they must be comfortable. This was proved over and over again in the submarine boats. If the men are to keep in a normal condition you must make them to $a^{-}$certain extent comfortable, and that is one reason why some of us advocate a larger, more roomy, and better protected craft than the aeroplane, such as it is known now.

\section{The Need for Experinexts.}

The difficulty in the development of the airship lies in the fact that its commercial use is restricted, and the cost of experimenting with it is very high. So great is the cost that systematic experiments can only be carried out by philanthropists or by Governments. There is perhaps no class of work in which experimenting must be started so absolutely from the very commencement of design, since every portion of the hull material and fabric has to be invented and developed. Moreover, these sperial materials find little use in other commercial undertakings so that assistance from collateral sources of demand for similar material is nonexistent. Unless we are to be out-distanced in the future by other countries in airship development, systematic and probably expensive experimenting will have to be undertaken in England, and the only people who can undertake it are the Government, and preferably the Admiralty. The urgency of the matter cannot be over-emphasized, since such development is not merely a matter of design, of shape, detail, etc ${ }_{n}$ as was the case in submarine boats, but it entails the gaining of experience of materials and fabrics, all of which have to be experimented with. And since the composition and treatment of similar materials is certain to be kept secret by whatever country develops the airship, we may well wake up one morning and find that we are absolutely unable to produce what other countries perhaps have produced, because we have not got an elementary 
notion or knowledge of the materials that we have to use, and thereforc. we may be without the slightest reply to what, if it is developed, will be: a very formidable class of scout. It was considerations such as these which led the late Board of Admiralty to build an airship at Barrow: That airship was built entirely as an experimental platform. No one who knew the necesssarily tentative nature of the work dreamed that the vessel would be more than a vast experiment on which to build future experience. No responsible person anticipated that the vessel would even leave her mooring post for at least six months after she was launched from her shed, during which time she could carry out her speed trials, which were very simple because it was only necessary to steam her to test her pace in varying strengths of wind, so that the whole of the speed factors and other information could be obtained in the same way as if she had not been attached to the mooring post. Experience would be afforded of weather conditions, mooring, leakage of gas, variation in weight due to varying hygrometer conditions, effects of aerial electricity, effects of variation of temperature, and deterioration of structure, which observations could only be carried out on a life-size model. These and numberless other experiments could have been carried out perfectly well at her post without her ever making a sensational trip. Unfortunately the vessel met with an accident at the commencement of her career, and has since not been publicly heard of. But that in consequence of this. accident further experimenting in the direction of rigid dirigibles should be discontinued is inconceivable. A failure'to achieve should only stimulate further exertion, and we may confidently look forward to increased activity on the part of the Admiralty, for if they allow the original experiments to drop it will be the first time on record that the Navy has run away from attempting to achieve because the attempt was difficult and courage was required to face temporary failure.

\section{- Importance of a Forward Policy.}

We must always be careful about ex cathedra opinions. I remember very well a very distinguished foreign admiral who stated that submarine boats were useless, and that they would never have them in his own particular navy. In less than three years that navy was supplied with submarine boats. That statement of his created a lot of harm; it produced a tremendous lot of opposition amongst influential people in England against submarine boats. It was always quoted. "So and so says they are useless, and they must be useless." That is one of the dangers we have to face when we are dealing with.a problem of the future, that the man of the present is apt to damp the whole of the ardour, official or otherwise, by making too definite statements and failing to appreciate what after all may really be very great possibilities. If England is to make up her position in respect to airship construction, and not to be found deficient in the day of need, we require a forward policy of spending money, perhaps considerable sums, and a courageous sympathy among those in authority which will enable them to wait patiently until systematic and slow laborious experiment wins past uninformed criticism, and at last attains the success which cannot be withheld from unstinted and wholehearted endeavour.

I am sure we ought to be very grateful to the author for bringing forward a paper so carefuliy thought out, supplied with such excellent diagrams, and upon which he must have spent considerable labour, and I am sure I am only echoing your wishes in according to him a very hearty vote of thanks for it. 